\title{
A múlt és a jelen pénzügyi válságainak ismerete a pénzügyi oktatás függvényében
}

\author{
Csiszárik-Kocsir Ágnes \\ Óbudai Egyetem \\ kocsir.agnes@kgk.uni-obuda.hu \\ Varga János \\ Óbudai Egyetem \\ varga.janos@kgk.uni-obuda.hu \\ Garai-Fodor Mónika \\ Óbudai Egyetem \\ fodor.monika@kgk.uni-obuda.hu
}

ÖssZeFoglaLó

A múlt válságai számtalan információt, adalékot adnak a jelen válságainak megértéséhez. A régmúlt és a közelmúlt krízisei azonos fejlődési fázisokon mentek keresztül a kibontakozásukat illetően, amelyre már több kutatás is rávilágított. Emiatt fontos, hogy ismerjük azok fejlődését, működését, csökkentve ezzel a jövő kríziseinek kialakulási valószínűségét. Fontos az is, hogy meg tudjuk különböztetni a buborékot a válságtól, mivel ez utóbbi csak akkor következik be, ha a buborék kipukkad. Ha azonban ez bekövetkezik, akkor a hatások közvetve vagy közvetlenül magukkal ragadnak mindenkit. A pénzügyi műveltség fejlesztése évek óta kihívás nemcsak hazánkban, hanem világszerte egyaránt. E folyamat során inkább a pénzügyi piacok működésének megértésére, az eszközök ismertetésére törekszünk, de vajon mennyire hangsúlyos a korábbi krízisek tárgyalása? Jelen tanulmányban arra vállalkozunk, hogy rávilágítsunk a régmúlt és a közelmúlt, valamint a jelen válságainak ismeretére, azok hatásainak érzékelésére a korábbi pénzügyi tanulmányok függvényében. Ehhez egy 2020-ban végzett kérdőíves kutatás eredményeit használjuk fel, széles körű szakirodalmi kutatással megalapozva azt. Célunk, hogy megvilágítsuk vagy megcáfoljuk a pénzügyi oktatás azon hiányosságait, amelyek fontosak a gazdaságban állandóan jelen lévő válsághelyzetek felismerésében és kezelésében.

KulCssZavaK: válság, buborék, pénzügyi oktatás, pénzügyi műveltség

JEL-кóрок: A20, E69, G01, N80

DOI: https://doi.org/10.35551/PSZ_2021_2_3 
A válság életünk velejárója, mondhatni társadalmi és gazdasági berendezkedésünk törvényszerü jelensége. A világtörténelem eddig is számos példát szolgáltatott arra, hogy a növekedési és visszaesési szakaszok meghatározott ütemben követik egymást, így soha sem volt jellemző ránk az unilineáris ${ }^{1}$ jellegü növekedés. Ehhez elég megtekintenünk a világ GDPjének alakulását, amely tökéletes bizonyítékot szolgáltat a növekedések és visszaesések egymásutániságára (lásd 1. ábra).

A válság ebből kiindulva már-már a gazdaságunk természetes állapotának is tekinthető, amely meghatározott időszakonként ismétlődő jelenségként definiálható (lásd 1. ábra). Ha el tudjuk ezt fogadni és elhisszük, hogy a válságok menetrendszerűen visszatérhetnek az életünkbe (nevezzük ezt innentől a természetes rendnek), akkor a tudatos felkészülésnek, az előkészületeknek és a felelősségteljes gondolkodásnak is helyet kell kapnia döntéseinkben. Davidson (2002) hivatkozik Keynes azon megállapítására, amely szerint a gazdaság olyan, mint egy motor. Időről-időre elromlik, de meg is lehet javítani. Ebben ott szerepel az is, hogy a motor, mint szerkezet, nem örökéletű és semmiképpen sem lehetünk olyan naivak, hogy azt hisszük: „a miénk sohasem fog elromlani”. Ez egy nagyon fontos tanulság, amit mindenképpen szem előtt kell tartanunk. Nemcsak a válságok visszatérése, de a világgazdaságban rejlő komplexitás is olyan leckét ad, amelyet érdemes mindig figyelemmel kísérni. Sokszor egy nagy válságjelenség kirobbanása egy adott országhoz vagy régióhoz köthető, esetleg valamely piacon meglévő anomáliák vezetnek el a válság kialakulásáig. Ma már egyértelmüen kijelenthetjük, hogy csak egyetlen világgazdaság létezik és ebben a rendszerben senki sem függetlenítheti ma-

\section{A VILÁG GDP-JÉNEK ALAKULÁSA 1960-TÓL} (A NÖVEKEDÉSEK ÉS VISSZAESÉSEK PÁRHUZAMA)

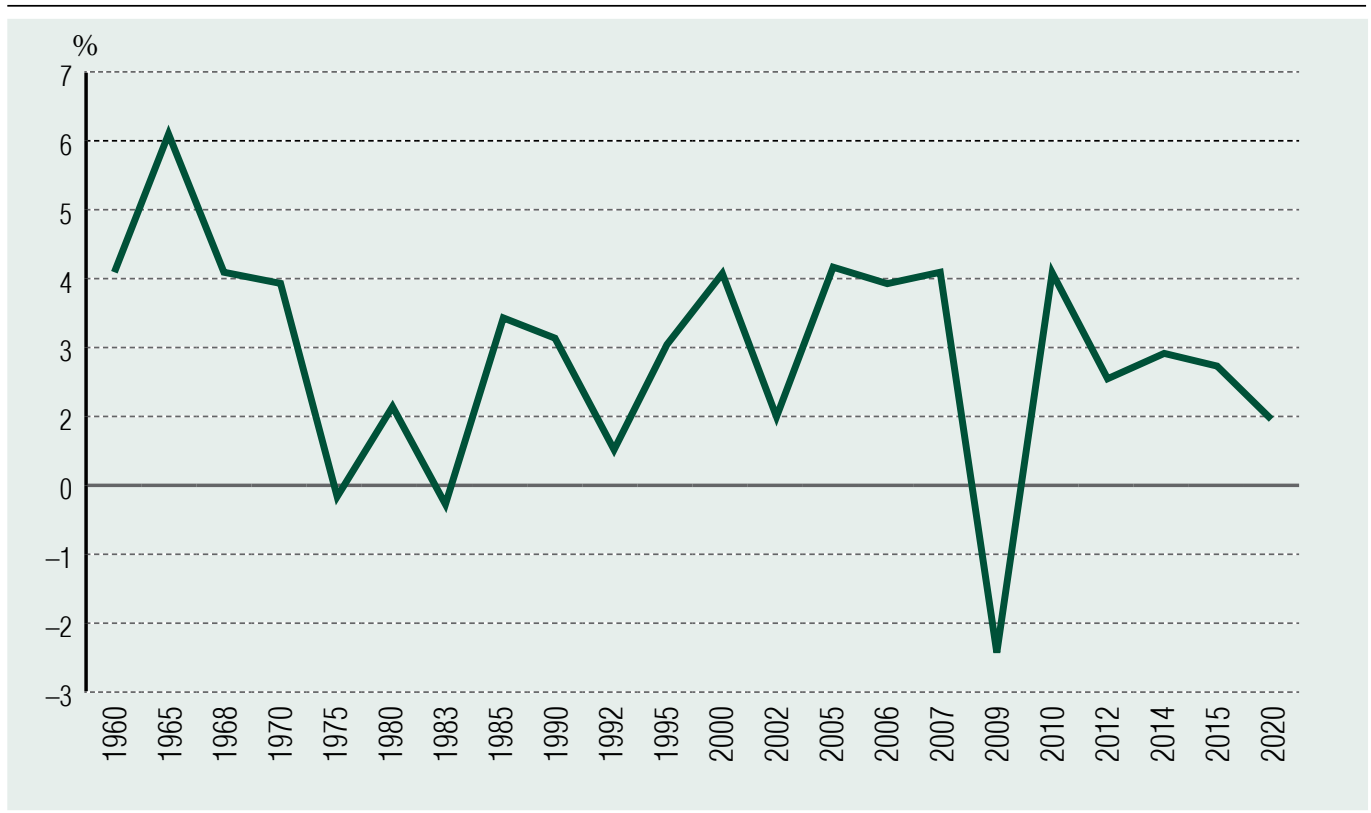

Forrás: The WorldBank Database adatai alapján saját szerkesztés 
gát annak folyamataitól. A gazdasági szereplők függősége ebben a rendszerben egyre erősebb és ez még inkább megerősíti bennünk azt az igényt, hogy sokkal felelősségteljesebben, sokkal tudatosabban kell bizonyos döntéseket meghoznunk, hiszen ezek a döntések nem pusztán a saját helyzetünket határozhatják meg. A világgazdaságban meglévő gazdasági komplexitást számos dolog alátámasztja. A World Economic Forum (WEF, 2019) kutatásai szerint a nemzetgazdaságokat a komplexitás alapján is lehet rangsorolni. A WEF a Harvard's Growth Lab úgynevezett Country Complexity Ranking (GCR) eredményeit felhasználva meghatározta a világ 10 legkomplexebbnek tekintett gazdaságát, amelyen Magyarország is a lista élén szerepel (!). A múltban a nemzetek közötti kereskedelem sokkal egyszerűbb volt. Csak néhány árucikk és késztermék áramlott egy maroknyi ország között. Ma már több ezer termék halad át a világ kikötőin, a digitális termékek és szolgáltatások világszerte összekapcsolódnak, ügyletek milliói köttetnek meg, amelyek tovább nehezítik az országok gazdasági aktivitásának mérését. A GCR-mutatóban azok az országok kerültek a lista élére, amelyek exportált termékei nagy változatosságot mutattak. Ezek az országok kifinomult és egyedi exportált termékekkel is rendelkeznek, azaz kevés másik ország gyárt hasonló termékeket. A Harvard's Growth Lab ehhez kapcsolódóan látványos és beszédes ábrát készített, amelyben megnevezésre kerül az is, hogy mely termékek exportja magyarázza a jelentősen magas komplexitás értéket (1. táblázat, 2. ábra).

Hasonló megállapításra jutott a The Observatory of Economic Complexity (OEC) intézet is, amely a gazdasági komplexitást az ECI (economic complexity index) -mutató értékével fejezi ki. E mutatót multidimenziós elemzéssel kapják, amelyből az országok között rangsort állítanak fel. Az OEC által készített jelentés szerint Magyarország itt is a lista elején helyezkedik el, a 2018-as eredmények szerint a 14. pozícióban volt a magyar gaz-

\section{A TOP10-0RSZÁG A KOMPLEXITÁS ALAPJÁN}

\begin{tabular}{|c|c|c|}
\hline Helyezés & Az ország megnevezése & Exporttermék \\
\hline 1. & Japán & Autógyártás, ICT \\
\hline 2. & Svájc & ICT, arany, csomagolt gyógyszerek \\
\hline 3. & Dél-Korea & ICT, autógyártás \\
\hline 4. & Németország & Integrált áramkörök, ICT, autógyártás \\
\hline 5. & Szingapúr & ICT, autógyártás \\
\hline 6. & Csehország & Autógyártás, járműalkatrészek \\
\hline 7. & Ausztria & ICT, turizmus \\
\hline 8. & Finnország & ICT \\
\hline 9. & Svédország & ICT \\
\hline 10. & Magyarország & Autógyártás, ICT \\
\hline
\end{tabular}

Megjegyzés: 2004-ig 132, 2005-tól már 133 ország szerepel a listán.

Forrás: atlas.cid.harvard.edu alapján saját szerkesztés 


\section{MAGYARORSZÁG KOMPLEXITÁS (GCR) -MUTATÓJÁNAK VÁLTOZÁSA AZ ELMÚLT 18 ÉVBEN}

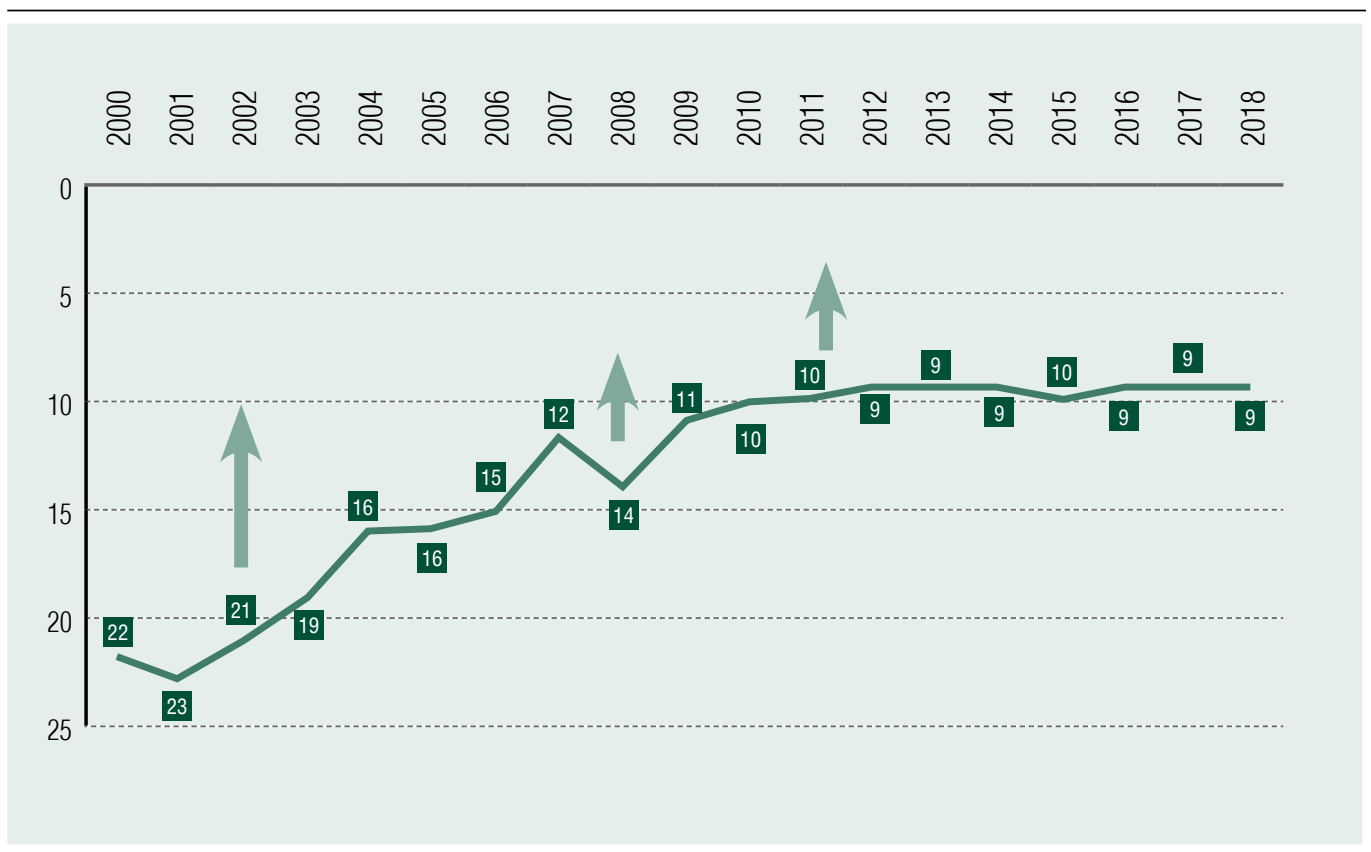

Forrás: atlas.cid.harvard.edu alapján saját szerkesztés

daság (OEC, 2020). A komplexitás mérésére előszeretettel szoktak úgynevezett globalizációs indexeket használni. Pálinkai és szerzőtársa szélesebb körben igyekezett összegyüjteni e mutatókat (Pálinkai, Miklós, 2014). Meglátásuk szerint a globalizáció szoros kapcsolatban áll a gazdasági komplexitással, hiszen a globalizáció eredményeképpen felerősödő nemzetközi kereskedelem, a pénzügyi mozgások, a személyek szabad áramlása, az infokommunikációs áramlások stb., mind megnövelték a komplexitás mértékét. Ha ehhez hozzáveszszük a világszerte országhatárokon túlra szerveződő ellátási láncokat, határon átívelő gazdasági megállapodásokat és érdekeltségeket, a multi- és transznacionális vállalatok elterjedését, az FDI-befektetések volumenének növekedését, akkor aligha vitatkozhatunk a komplexitásunk alakulásán. Eközben Európán belül is egyre jobban függünk egymástól, hiszen az Európai Unió létrehozása új függőségi és kölcsönös egymásrautaltsági mechanizmust hozott létre. A gazdasági komplexitás erősítéséhez olyan tényezők járultak hozzá, mint például a Négy Szabadság Elve vagy a Bank- és Tőkepiaci Unió (utóbbi CMU, Capital Market Union), amely új pénzügyi felügyeleti rendszert teremtett a válságok megelőzése, valamint hatékonyabb kezelése érdekében (consilium. europa.eu; ec.europa.eu). A már említett Pálinkai, Miklós (2014) tanulmány megvizsgálta Magyarország helyezéseit a globalizációs indexekben. Arra a megállapításra jutottak, hogy gazdaságunk a világ legkomplexebb gazdaságai közé sorolható. Ezt erősítette meg ezekben az években az Ernst and Young (EY) is, amely globalizációs indexével Magyarországot a világ legnyitottabb és legkomplexebb gaz- 
daságai között említette meg (ey.com, 2020). Weiss és szerzőtársai által 2018-ban készített Globalization Reportban a vizsgált 42 országból Magyarország a 10. helyen szerepelt (iberglobal.com, 2018). A 2020-as KOF globalizációs indexben a 2018-as adatokat alapul véve Magyarország a 16. helyen szerepel, ezzel szintén a lista élmezőnyéhez tartozva. Ez az index megpróbálja felmérni a jelenlegi gazdasági és pénzügyi áramlásokat, kapcsolatok és hálózatokat. A svájci KOF-intézet kutatásai tanulságos képet festenek le a magyar gazdaság elmúlt 50 évéről. Megállapításai szerint a magyar gazdaság lényegesen összetettebb lett az elmúlt évtizedekben, mint ahogy az a világátlagra jellemző. (lásd 3. ábra)

A gazdasági komplexitást erősíti meg a World Investment Report 2020-as adatsora. Az Európai Unión belül a 15. helyet foglaljuk el az FDI-beáramlást tekintve, megelőzve olyan országokat, mint Ausztria, Dánia vagy Szlovénia (unctad.org, 2020). Ez arra enged következtetni, hogy bár a beáramlást tekintve nem hozzánk érkezik a legnagyobb összegü FDI az Unióban, az ország GPD-jéhez képest ez mégis jelentősnek tekinthető, ami tovább erősíti a komplexitást és a függőséget. Talán ez a legfontosabb megállapítás, hogy a komplexitás egyben a kölcsönös függőséget is elősegíti, így nem véletlen az, hogy a világot egy nagy dobhoz lehetne hasonlítani. Ha az egyik oldalát megütjük, a rezgéseket a mások oldalon is érezni lehet. A gazdasági komplexitás és a kölcsönös függőség így segítette elő, hogy a válságok is bizonyos esetekben futótűzként terjedjenek el a világon, hiszen minden mindennel összefügg. Ez különösen fontos olyan országok esetében, amelyek a komplexitás vagy a világgazdasági nyitottság tekintetében különösen kitettek és az előző eredményeket lát-

\section{MAGYARORSZÁG ÉS A VILÁG KOMPLEXITÁSÁNAK VÁLTOZÁSA AZ ELMÚLT 50 ÉVBEN}

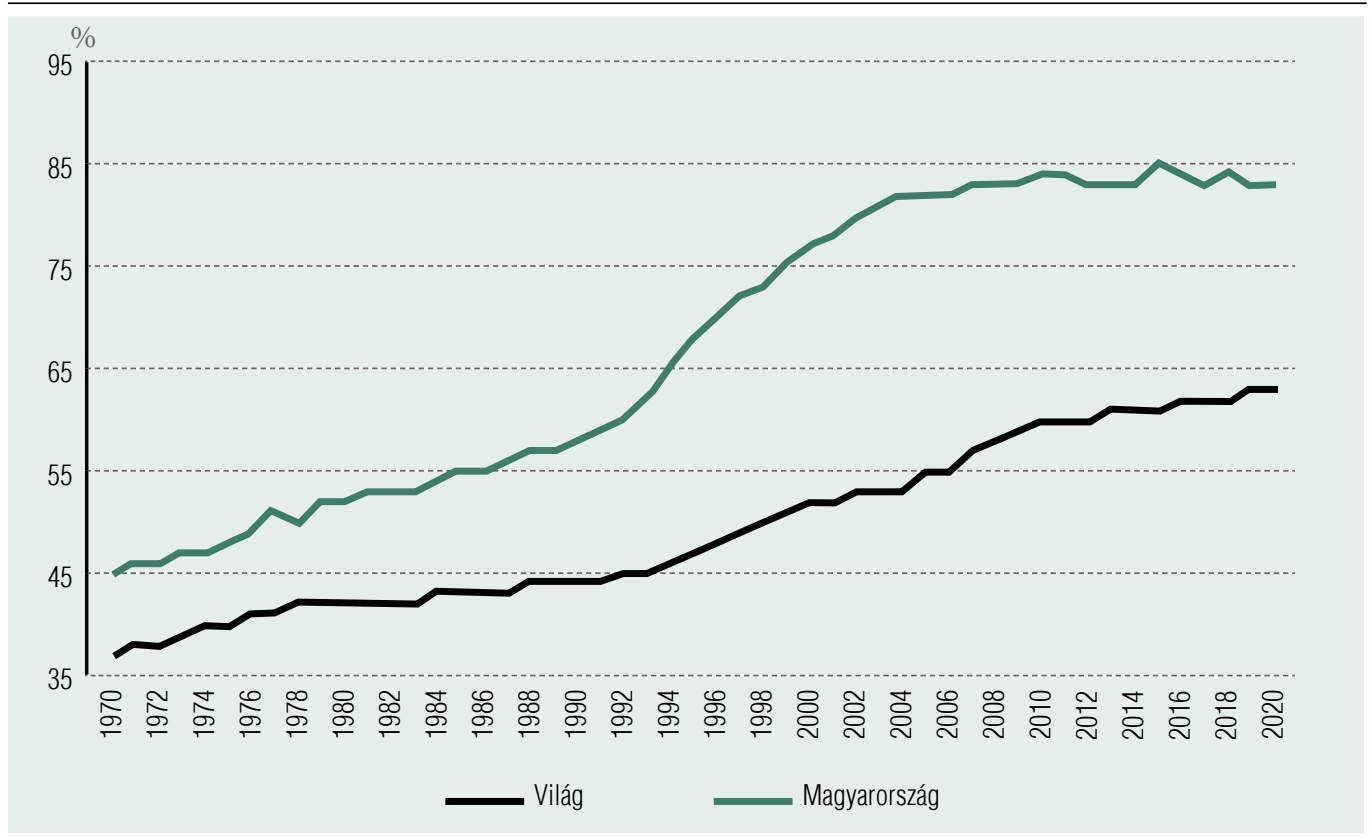

Forrás: kof.ethz.ch alapján saját szerkesztés 
va Magyarország is ezek közé sorolható. Larry Greiner híres növekedés-irányítás modelljében a szervezetek esetében is megemlíti azt a ciklikusságot és természetes állapotot, amelyeket már a tanulmány elején is említettünk. 2009ben írt cikkében arról ír, hogy a szervezetek életében is normális jelenség a válság. Ugyanakkor hozzáteszi, hogy figyelembe kell venni a cég történetét, vagyis életciklusának előző szakaszait, így tanulni kell ezekből. A növekvő cég vezetése előre láthatja a következő válságot és jobban felkészülhet annak kezelésére (Greiner, 2009). Ez olyan, mintha valamiféle tudatos előrelátásra, előre tekintésre hívná fel a figyelmet és ebben a vezetést teszi felelössé. Az eddigiek alapján elmondhatjuk, hogy a válságok és a gazdasági komplexitás képesek felerősíteni egymást. (lásd 4. ábra)

A válságok a gazdasági élet természetes velejárói. A múlt eseményeit vizsgálva megállapítható, hogy azok gyakorlatilag egy gyökérről táplálkoznak. Az emberi hiszékenység, kapzsi- ság, a gyors meggazdagodás lehetősége emberek ezreit taszította nyomorba már. Mindezeket bizonyítja a tulipánmánia, a Mississippi és a Déltengeri Társaság esete, ahol az emberi kapzsiság vezetett a buborékok kialakulásához, majd azok kipukkanásához (Madarász, 2009, 2011a, 2011b). A válságok természetrajzának megismerése számos kutatót mozgatott már meg, közülük kiemelkedő Hyman Minsky munkássága. A pénzügyi rendszert, ha nem szabályozzák, akkor önmagát pusztítva buborékokat növeszt. Ezt az összefüggést Minsky, amerikai közgazdász már évekkel ezelőtt megfogalmazta. A Minsky-elmélet szerint minden válságnak hét, egymástól jól elkülöníthető szakasza létezik, és kimondja, hogy a válságok igen sok szempontból hasonlítanak egymásra. A válságok szakaszai:

Elmozdulás (displacement)

Minden krízis egy zavarral kezdődik, vagyis valami szokatlan esemény történik a piacon

\section{A KOMPLEXITÁS MINT VÁLSÁGKATALIZÁTOR}

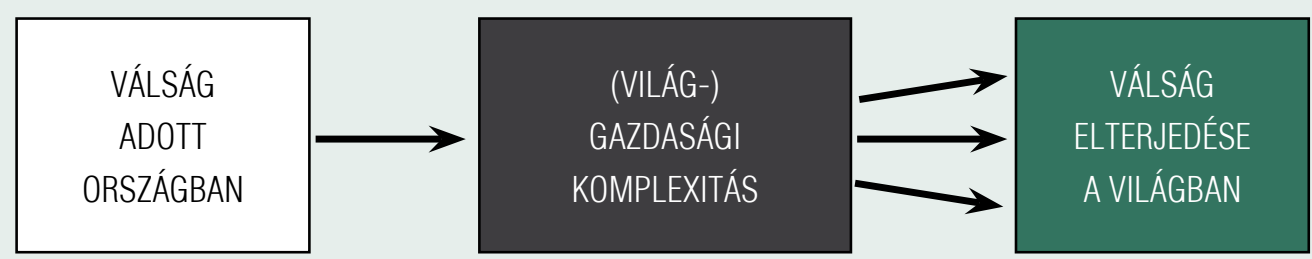

VÁLSÁGKATALIZÁTOR 
(gazdaságpolitikai változás, kamatlábcsökkentés). Ez a változás a gazdaság bármely szektorát érinthetni.

\section{2 Áremelkedés (prices start to increase)}

A változás hatására az érintett szektorban az árak elkezdenek emelkedni. A gazdaság szereplői kezdetben alig érzékelik az áremelkedést, de amennyiben a hatás tartósnak bizonyul, a szereplők felfigyelnek rá.

\section{Hitelezési boom (easy credit)}

A magas árak önmagukban nem elegendőek egy buborék kialakulásához, ehhez valamilyen „fütőanyag” kell, ami nem más, mint az olcsó hitel. Ha a pénzügyi szektor szereplői nem fütenék az így kialakult helyzetet az olcsó hiteleikkel, a változással érintett szektor hamarosan visszatérne a normál kerékvágásba. Az olcsó hitelek vonzzák a szektoron kívüli szereplőket, akik a nagyobb haszon reményében kapcsolódnak be a gazdaság ezen érintett szegmensébe.

\section{Túlkereslet (overtrading)}

Az olcsó hitelek hatására a piacok óriási növekedésnek indulnak, amely a forgalom növekedésében, és számos esetben hiányban ölt testet. Az árak elkezdenek növekedni, ami a kínálati oldalon hatalmas profitnövekedést indukál. Így a szektor még több külső szereplőt vonz, és az árak irányíthatatlanná válnak. A gyorsuló árnövekedés egyre több meggondolatlan és kapzsi szereplőt vonz a piacra. Ahogy a tüznek is több fára van szüksége, hogy jobban égjen, így a buborékok is több kívülállót igényelnek.

\section{Eufória (euphoria)}

Az így kialakult buborék már nem tud tovább növekedni. A szakértők már látják a közelgő válságot, és figyelmeztetnek is erre, de a szereplők ezt nem akarják meghallani. Az árak tovább száguldanak, és elkezdődik a spekuláció. A spekulánsok tudják, hogy az árak nem növeked- hetnek a végtelenségig, de ezt tagadják, hogy még több külső szereplőt vonzzanak a piacra. A spekulánsok egészen addig a piacon maradnak, amíg a helyzet stabilnak tűnik, azonban a buborék kipukkanása előtt kilépnek, és a „kevésbé hozzáérto"” szereplők bennragadnak.

\section{6}

Profitrealizálás (insider profit taking)

Egyes szereplők hatalmas profitra tesznek szert a buborék kialakulása során, azonban más szereplők hatalmasat buknak. A „bennfentesek” csendben (tömött zsebbel) kiszállnak, ami már a vég kezdetét jelzi.

\section{Pánik (revolusion)}

A pánikot számos tényező válthatja ki: a szektor profitrátája elkezd drasztikusan csökkenni, egy váratlan rossz hír, így az eufóriából egy csapásra pánik lesz. A szektor „lángokban áll”, és mindenki menekül. Beköszönt a pánik, az árak csökkennek, a profitráták zuhannak, az olcsó hiteleknek vége, veszteségek halmozódnak fel, mindenki menekülne, de nincs kiút.

Minsky ezen elméletével megfogalmazta a buborékelmélet paradoxonát (Shostak, 2007): mindenki tudja, hogy az olcsó hitelek, a túlkereslet és az eufória kombinációja előbbutóbb végzetes lesz, mégis a világ időről időre beleesik ebbe a csapdába (Lentner, 2015), így a készletbuborékoktól kezdve az ingatlanpiaci buborékig eddig a buborékok sokféle formájával találkozhattunk. Mint látható, a felsorolt állomások szinte minden válság kapcsán pontról pontra nyomon követhetők (Beshenov, Rozmainsky, 2015).

Többé nem vitatkozhatunk a válságok természetéről. Többé nem arra a kérdésre kell keresnünk a választ, hogy miért alakult ki a válság és mi miért vagyunk ebben nyakig benne? A természetes rend és a komplexitás már választ adott erre a kérdésre. A következő, 5. ábra még inkább megerősíti a gazdaságok ciklikus természetét. 


\section{A CIKLIKUSSÁG TíPUSAI}

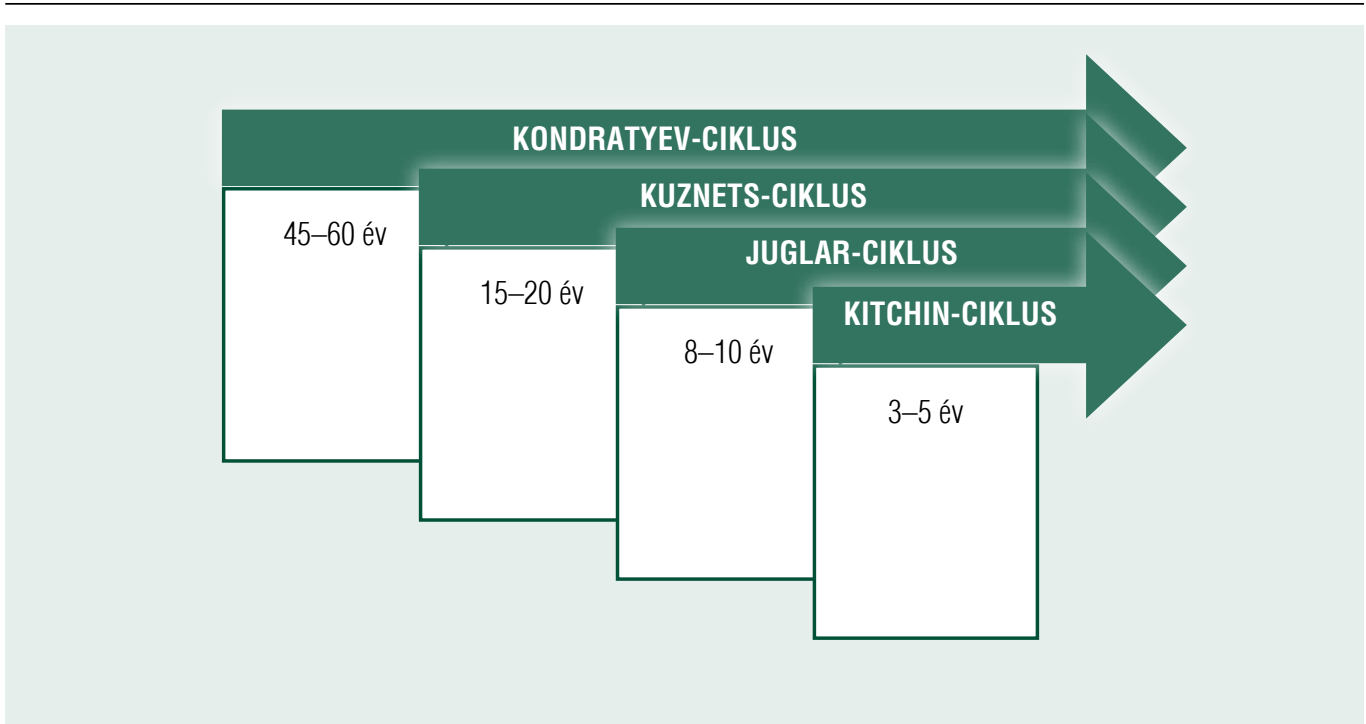

Forrás: Kehl, Sipos 2007 alapján saját szerkesztés

Fel kell készülnünk és felelősségteljesen kell gondolkodnunk! Egyetlen válságeseményt sem szabad lebecsülni, mert olyan összetett világgazdasági rendszerben, amelyben élünk, könynyen elhatalmasodhat rajtunk egy probléma. Ebben a rendszerben mindenki a stabilitás fenntartásában érdekelt (vagy legalábbis érdekeltnek kellene lennie), így mindenki a maga területén tehet a legtöbbet. A válság egy szervezet életében azt jelenti, hogy jövőképe és küldetése veszélybe kerülhet egy kedvezőtlen esemény hatására (Farkas, 2013). Egy nemzetgazdaság vonatkozásában a válság a GDP tartós visszaesését vagy stagnálását jelenti. Ennek rövidebb távú folyamata a recesszió. Egy család vagy háztartás esetében ez a jövedelem kiesését, a munkanélküliség megjelenését, az életszínvonal visszaesését vagy az életminőségi mutatók romlását eredményezheti. A válság természetes rendje és a komplexitás elismerése része kell, hogy legyen kultúránknak. Ez azt jelenti, hogy döntéseink kialakításánál - legyen szó kormányzati vagy akár egy háztartás pénzügyi döntéséről - figyelembe kell venni a jövőben várható hatásokat. A felsoroltak arra adnak bizonyítékot, hogy a válságok valóban menetrendszerűen visszatérő jelenségek, amelyekkel az országok vagy a vállalatok éppúgy szembe kerülhetnek, mint a háztartások.

Minden mindennel összefügg és egy nagyobb válság hatása nem korlátozódik le csupán a szervezeteknél, hanem azt sokszor a társadalom szélesebb köre is érzékeli. Ez újfent bizonyítékot ad a komplexitásra. A válságok hatásai nem kizárólag a GDP-ben mérhetők, hanem sokkal érdekesebb a társadalmi depreszszió $^{2}$ vizsgálata, amely a válságok társadalomra gyakorolt hatását foglalja össze. Kedvezőtlenebbül alakulnak a jövőbeni kilátások, gyengül a bizalom, romlik a társadalmi tőke, az emberek félnek, csökken a beruházási kedv, mindenki kivárásra játszik. Ha nem sikerül expanziót elősegíteni, hosszú évekre megrekedhet a gazdaság és a válság tartósan begyűrűzik. Először a válságról vallott gondolkodásunkat kell megváltoztatni és tudatosabban kell készülni a 
jövőre. A komplexitás ma már tény és adottság. Ez olyan tényező, amely képes felerősíteni egy esemény kedvezőtlen hatását az egész világra. Mindez azt is jelentheti, hogy a válságok bárhol és bármikor kirobbanhatnak, de nekünk nem kellene karba tett kézzel ülnünk és akkor döntéseket hozni, amikor már válságban vagyunk. A (jó) döntéseket akkor is meg lehet hozni, amikor a válságjelek még távolinak tünnek. Abban kellene sokat fejlődnie a gazdasági szereplőknek, hogy hogyan tanulhatnak meg együtt élni a válságokkal, és hogyan használhatjuk ki a gazdasági komplexitásban rejlő előnyöket. A válságok nagyon sok esetben a pénzügyekhez kapcsolhatók, így a szervezetek és a háztartások részéről is felelősebb pénzügyi döntésekre lenne szükség. Már említésre került, hogy ebben az igen komplexnek és mára már turbulensnek is tekinthető üzleti környezetben mindenkinek a stabilitás fenntartására kellene törekednie.

A stabilitás viszont a kiszámíthatóság megteremtését jelenti, amely tudatos és felelős pénzügyekkel is elősegíthető. A háztartások vagy a vállalkozások sokat tehetnének egyéni szinten azért, hogy a stabilitást elő lehessen segíteni. Ehhez érdemben fejleszteni kellene a társadalom pénzügyi kultúráját. Az angolszász és hazai irodalomban is igencsak vita tárgyát képezi a pénzügyi kultúra fogalma. Sok esetben keverednek ezek a kifejezések: pénzügyi tudatosság, pénzügyi műveltség, pénzügyi jártasság, pénzügyi kultúra, de ezek mégsem jelentik teljesen ugyanazt. Ennek ékes bizonyítéka Csorba (2020) tanulmánya, amely a kultúrából kiindulva a műveltségen át jut el a pénzügyi kultúrához. Cikkében kifejti, hogy a pénzügyi tudás, a műveltség és a tapasztalat együttesen járul hozzá a pénzügyi kultúra állapotához. Egy másik fontos ábrájában azt is megmutatja, hogy egy társadalomra jellemző kulturális értékek alapvetően összefüggenek a pénzügyi döntéseik milyenségével, így magát a kulturális tényezőket is értékelni kell, amikor a pénzügyi kultúra állapotát igyekszünk vizsgálni (Sági et al., 2020a; 2020b). A pénzügyi kultúra az elmúlt években több kutatás és szakmai projekt témáját is képezte. Különösen a 2008as válság hívta fel a figyelmet leginkább erre a területre és most a 2020-as koronavírus-válság újfent megvilágításba helyezte annak állapotát. Bár a téma jelenleg is időszerűnek tekinthető, a pénzügyi kultúra fogalma már az 1900-as években is felfedezhető volt (Kovács et al., 2012). Béres több alkalommal folytatott kutatásokat ebben a témában. 2012-es cikkében szerzőtársával arról ír, hogy a pénzügyi kultúra sajátos koncepciónak fogható fel. Ez azt jelenti, hogy ebben keveredik a pénzügyi tudás, a pénzügyekben való jártasság és tapasztalat, a pénzügyi készségek és a tudatosság is (Béres, Huzdik, 2012). A tudatosságot Nagy és Tóth (2012) is kiemelik, míg Süge (2010) szerint a pénzügyi kultúra minden olyan dolgot magában foglal, amely segít az embereknek a pénzügyi kérdésekben eligazodni. A pénzügyi kultúra egy itthon szélesebb körben alkalmazott fogalmát az MNB határozta meg. A jegybank értelmezésében olyan készségeket jelent, amelynek segítségével az egyének képesek a döntéseikhez szükséges pénzügyi információkat azonosítani, megszerezni, értelmezni és ezek alapján döntést hozni. Képesek arra is, hogy döntésük lehetséges jövőbeni következményeit elemezni tudják (MNB, 2008).

Ebben a meghatározásban is a tudatosság, a rendszerszemlélet, az előre tekintés és a felelős, fenntartható gondolkodás jelenik meg. A mi értelmezésünkben a felelős pénzügyek úgy jelennek meg, ha a jelenben meghozott pénzügyi döntéseink nem veszélyeztetik a jövőbeni fogyasztásunkat. A felelős pénzügyi gondolkodás figyelembe veszi azt is, hogy a jövőben bekövetkezhetnek kedvezőtlen események is, amelyek alapvetően negatívan érinthetik a pénzáramlásainkat. A válságok természetes rendje itt jelenik meg, hiszen nagyon sok gazdasági szereplő nem rendelkezett elegendő tartalékkal, hogy 
egy válságos időszakot is túl tudjon élni. Az angolszász irodalomban a pénzügyi műveltség gyakrabban megjelenik, mint a pénzügyi kultúra kifejezés. Atkinson és Messy (2012) a pénzügyi képességek szerepét hangoztatja, hasonlóan $X u$ és Zia szintén 2012-es tanulmányához. A pénzügyi képességek nem az egyén veleszületett adottsága, így azt folyamatosan fejleszteni kell. Lusardi és Mitchell 2014-es tanulmánya a fenntartható pénzügyekhez kapcsolódik. Véleményük szerint, amikor magasabb a jövedelem, egy racionálisan gondolkodó egyén kevesebbet költ, hogy a fogyasztási szintjét a jövőben is fenn tudja tartani (Lusardi, Mitchell, 2014). A pénzügyi képességek és készségek fejlesztésére szólít fel Botos (2012) és $N e ́$ meth (2020) szerzőtársaival együtt, akik szerint a szocializáció, a család és az oktatási rendszer is felelőssé tehető a pénzügyi kultúra fejlesztéséért. Meglátásuk szerint a gyengébb pénzügyi kultúra összefüggésbe hozható a rossz döntésekkel. Kovács (2012) szintén hasonló következtetésre jut. Véleménye szerint a gazdasági válság rámutat a pénzügyi kultúra fontosságára és látszik az is, hogy a magyar társadalomnak mely területeken kellene hangsúlyosan is fejlődnie. Huston (2010) szerint a lakosság döntései jól tükrözik a pénzügyi kultúra állapotát. Sokan eladósodnak, a háztartások csődrátái magasak voltak, a vállalkozásoknak nincs számottevő tartaléka akkor, amikor a válságban kiesnek a bevételek. Mandell és Klein (2009) kiemelik, hogy a pénzügyi kultúra hiánya akadályát jelenti az egyéni céloknak. Mivel az egyének nem képesek jól értelmezni a pénzügyi információkat, így döntéseik a rövid és hosszú távú céljaik ellen hathatnak. Kurt Tepperwein 2000-ben megjelent könyvében hangoztatja, hogy az emberek többsége érzelmi síkon közelíti meg a pénzt, de a megfelelő pénztudat első lépése az lenne, hogy hogyan tudjuk felelősségteljesebbé tenni létünket. Ugyanakkor a szerző azt is kiemeli, hogy nem az számít, mennyi pénzt tudunk birtokol- ni egy időben, hanem az, hogy sokkal jobban bánjunk vele, mint korábban (Tepperwein, 2000). A pénzügyi kultúra nem más, mint képességek és készségek összessége, amellyel hatékonyabb választ lehet adni azokra a változásokra, amelyek közvetlenül a pénzügyeinket is érintik. A pénzügyi kultúra értékrendet alakító tényező, ugyanakkor az értékrend is képes befolyásolni a pénzügyi döntések milyenségét. A magas szintű pénzügyi kultúra azt mutatja, hogy a gazdasági szereplők olyan pénzügyi képességekkel (pénzügyi műveltséggel) rendelkeznek, amelyekhez nagyobb felelősségtudat, előrelátás, biztonságra való törekvés, jövőorientáltság, felkészültség társul. Mindez nem jelenti azt, hogy a magas pénzügyi kultúrával rendelkező országokban kerülnék a kockázatot vagy nem fektetnének be. Éppen ellenkezőleg, csupán azt sokkal ésszerűbben és racionálisabban teszik meg, számítva mindazon tényezőkre, amelyek a gazdasági szereplők jövőjét esetlegesen kedvezőtlenül érinthetik. A pénzügyi kultúra ebben a felfogásban nem csak a pénzügyi képességek összességét jelenti, hanem a gazdasági szereplők sajátos viselkedését és hozzáállását is, amely kiszámíthatóságra, tervezhetőségre, egyértelműségre törekszik a mindennapi pénzügyeik során.

Az elmúlt időszakban a hazai online médiaanyagokban a következő információk jelentek meg (a teljesség igénye nélkül):

- Piac és Profit (2019). A magyarok többsége csak hallomásból ismeri a megtakarításokat.

- Növekedés.hu (2020). Átlagosan 400 ezer forint megtakarítása van egy magyar fiatalnak, de 45 százaléknak nincs félretett pénze.

-24.hu (2020). A magyarok zömének elérhetetlen a tisztességes nyugdíjtartalék.

- Bankmonitor.hu (2020). A magyar lakosság megtakarítási rátája 7-13 százalék közötti.

-Aegon (2020). A magyarok 43 százalékának nincs megtakarítása. 
Az eddigieket áttekintve és összegezve a következő pontokat emelhetjük ki.

(1) A válság a gazdaság természetes állapota, időszerűen visszatérő jelenség.

(2) A válságokra úgy kell gondolnunk, mint az életünk szerves részére, így nem pánikot vagy félelmet kell éreznünk ezzel kapcsolatban, hanem egy megoldandó feladatot kell látnunk benne, amelyen át kell esnünk.

3 A válságok ciklikusan visszatérnek, időről-időre megjelennek életünkben, így a válságkezelést már akkor is el lehet kezdeni, amikor még semmilyen válságjelet nem érzékelünk (prevenció és felkészülés), vegyük ezt tudomásul és már ma készüljünk a következő válságra.

(4) A gazdasági komplexitás olyan jelentős mértékű, hogy egy kisebb válságesemény is képes lehet világgazdasági recessziót okozni. Minden mindennel összefügg és a komplexitás csak még jobban fokozza a válság kialakulásának lehetőségét. Ilyen szempontból sosem lehetünk nyugodtak és érdemes felkészülni a „mi történik, ha rosszabbra fordulnak a dolgok" kérdésre.

5 Nem szabad naívnak lennünk, hogy a válságok vagy a komplexitás ránk nem hat.

6 A válságok a legtöbb esetben pénzügyeinket érintik, így a pénzügyi kultúránkat mindenképpen fejleszteni kellene.

(7A pénzügyi döntéseinket úgy kellene meghoznunk a jelenben, hogy azzal ne veszélyeztessük a jövőbeni fogyasztási szintünket.

8 A felelősen gondolkodó gazdasági szereplő gondol arra az időszakra is, amikor bevételei a kiadásaihoz képest elmaradnak (a tartalékolás óvatossági vagy biztonsági szempontból is indokolt lehet).

9 A válság idején fejlesztéseket eszközölhetünk tartalékokból, vagy képezhetjük munkatársainkat, esetleg innovációkat is megvalósíthatunk. Érdemes a szervezetnél fejlesztési vagy reagálási alapot képezni (nevezhetjük ezt rugalmassági tartaléknak is), amely a válságkezelés idején finanszírozhatja részben vagy egészben a válságkezelést,
(10) Válság idején nehezebb lehet hitelhez jutni, így a finanszírozás megoldása miatt is érdemes fejlesztenünk pénzügyi műveltségünket.

(1) Fontos lenne, hogy időben és megfelelően reagáljunk. Ne engedjük, hogy hiányos pénzügyi ismereteink gátat szabjanak a jó döntéseknek, képezzük és fejlesszük magunkat, erősítsük a pénzügyi kultúránkat.

(12 Tekintsünk ki környezetünkre, tanuljunk a múltbeli válságokból és építsük tudatosabban, felelősségteljesebben a jövőnket, nemcsak pénzügyi szempontból.

\section{ANYAG ÉS MÓDSZER}

A tanulmányban releváns hazai és nemzetközi szakirodalmak szisztematikus feldolgozása mellett primer kutatásunk részeredményeit mutatjuk meg. Primer adatfelvétel keretében kvantitatív kutatást folytattunk le: előtesztelt, sztenderdizált kérdőíves online megkérdezés formájában. Az alanyok rekrutálása hólabdamintavételi eljárással történt, melynek eredményeként 6873 értékelhető kérdőívet kaptunk. A kutatási segédeszköz kizárólag zárt kérdéseket tartalmazott, nominális mérési szinten (egy- és többválasztásos kérdések formájában), továbbá metrikus skálákat (Likert-skála és szemantikus differenciál skála) a fogyasztói attitűdök és értékrend elemzése céljából. A kutatási segédeszköz témaköreinek kialakítása a releváns szekunder adatelemzés eredményeként valósult meg. $\mathrm{Az}$ egyes válaszalternatívák véglegesítésére - a kutatási segédeszköz előtesztelésére - kvalitatív eredmények fényében került sor. Ezen kvalitatív kutatási etap keretében 10 mini-fókuszcsoportos interjút készítettünk, mely során az alanyok kiválasztása szintén hólabda-módszerrel történt.

A minifókuszok egyenként 3-4 fö részvételével megvalósult, nemek és életkor tekintetében heterogén összetételü csoportos irányított beszélgetések voltak. A kvalitatív kutatás keretében fó cél a kvantitatív kutatás megalapozá- 
sa, a sztenderdizált kérdőív véglegesítése és a kutatási hipotézisek körvonalazása volt.

A kvalitatív fázis eredményeként véglegesített kvantitatív kutatási segédeszköz témakörei az alábbiak voltak: válságok megítélése, válságok hatásának elemzése a digitális készségek, gazdasági ismeretek és menedzsment kompetenciák megítélésének fényében, a bankválasztás és a szolgáltató iránti lojalitás kérdése, banknál maradás feltételei. Jelen tanulmányunkban a kutatási projektünk kvantitatív fázisának részeredményeire fókuszálunk. Azon belül is kiemelten kezeltük a válságok hatásának elemzését, valamint a válságok megítélése és az alanyok pénzügyi előképzettségének mikéntje közötti kapcsolat vizsgálatát.

A kvantitatív eredmények feldolgozása során leíró statisztikát, kettő- és többváltozós elemzéseket alkalmaztunk SPSS 22.0 szoftver felhasználásával. Jelen tanulmányban a leíró statisztikai eredmények mellett egyes nominális mérési szintek közötti összefüggés-vizsgálat eredményeit mutatjuk be, amely során a statisztikai összefüggések megállapításához a Pearson-féle Khi-négyzet szignifikancia értékeit vettük alapul, míg a belső összefüggések megállapításához és elemzéséhez a korrigált sztenderdizált reziduumok abszolút értékeit vettük figyelembe.

A kvantitatív kutatási fázis során fó célunk volt a következő hipotézisek elemzése.

H1: A pénzügyi-gazdasági előképzettség és a vizsgálatba vont válságok ismertsége között statisztikailag is igazolható összefüggés van.

H1/b: Akik pénzügyi, gazdasági tanulmánynyal rendelkeznek, azok jobban ismerik a vizsgált válságokat.

H2: A pénzügyi-gazdasági előképzettség és a vizsgálatba vont válságok okozta hatás mértékének megítélése között statisztikailag is igazolható összefüggés van.

A tanulmányban ismertetésre kerülő részeredmények prezentálásának logikai vázát az említett hipotézisek értékelése adja. A min- ta szociodemográfiai föbb ismérvei a következők: a megkérdezett 6873 fö 50,6 százaléka férfi, 49,4 százaléka nő. A megkérdezettek mindössze 7,2 százaléka bír alapfokú végzettséggel, 57,2 százalék középfokú, 26,3 százalék alapdiplomával, valamint 9,3 százalék mesterdiplomával rendelkezik. Életkor tekintetében elmondható, hogy a minta legnagyobb hányadát (39,4 százalék) a Z-generáció tagjai (18-25 év) adják. Őket követte 21,8 százalékkal a 2635 év közötti és 17 százalékkal pedig a 36-45 év közötti válaszadók köre. A 46-55 év között mintatagok 13,1 százalékban képviseltették magukat a mintában, míg az 55 évnél idősebb kitöltők mindössze a minta 8,5 százalékát tették ki. Tekintettel arra, hogy kutatásunk hipotézise szerint a pénzügyi-gazdasági előképzettség és a válság megítélése között statisztikailag is igazolható összefüggés van, így lényegesnek tartjuk jellemezni ebbéli ismérv mentén is a mintánkat. A válaszadóink több mint fele (57,1 százalék) nem rendelkezik gazdaságipénzügyi előképzettséggel, az ilyen ismeretek a megkérdezettek 57,1 százalékát jellemzik.

\section{EREDMÉNYEK}

Ahogy a szakirodalmi áttekintésben is utaltunk már rá, a válságok ismerete nagyon fontos része a gazdaságtörténeti tudásnak. Válságok mindig is voltak, és mindig is lesznek, ami miatt érdemes ismernünk azokat részleteiben. A válságok egymásból merítkeznek, mondhatni azt is, hogy a kiindulási alapok tekintetében nincs új a nap alatt. A kutatás jelen tanulmányban ismertetett részében azt próbáltuk feltárni, hogy a mintába bevont válaszadók hogyan és milyen hatásúnak értékelik a korábbi gazdasági válságokat a korábban kapott (vagy nem kapott) pénzügyi oktatásuk függvényében. Ennek érdekében felsoroltuk a korábbi releváns, és mérföldkőnek számító válságokat a teljesség igénye nélkül, majd azok hatásának mértékére kérdez- 
tük rá, ahol a 4 jelentette a legerősebb hatást. A vizsgálat célja annak feltárása volt, hogy miként vélekednek a válaszadók a korábbi válságok hatásairól, mennyire optimisták, avagy pesszimisták, rávilágítva ezzel a jövőbeli és a mostani koronavírus-válsággal kapcsolatos várakozásokra is. A vizsgálat során leíró statisztikai módszereket, valamint összefüggés-vizsgálatokat végeztünk, melyek eredményeit a tanulmány további részeiben ismertetünk.

Első ízben azt szűrtük, hogy a válaszadók mekkora hányada ismeri az általunk vizsgált válságokat, melyek a világtörténelem legjelentősebbjei közé tartoznak. Az ismertség, az attitűd kognitív része azért fontos elem, mert befolyással bír az adott, és a további válságok iránti attitűd affektív részére is. Ha valamilyen gazdasági jelenséget - annak okát, hatásait ismerjük, akkor ez a tanulás pszichológiai folyamatának eredményeként befolyást gyakorol a későbbi válságok megítélésére. Ahogy az ismeret hiánya is befolyásoló elem, csak épp a kognitív disszonancia jelenségét okozva: ismeret hiányában generálunk érzelmi és cselekvési aktivitást, azaz a válságot - okát, lehetséges hatásait - nem ismerjük. A hiányos kognitív szint pedig pozitív vagy épp negatív affektív szintet eredményez, azaz generálhat félelmet vagy épp túlzott magabiztosságot egyegy gazdasági jelenséggel szemben. Egyik alternatíva sem szerencsés, ha azt nem alapozza meg a tudatosság, a megfelelő ismereti szint. Az egyes válságok ismertségének mértéke tehát azért fontos adat, mert a válságok egymásból táplálkoznak, a gyökerek sok esetben közösek, ahogy erről tanulmányunkban már korábban szó esett (lásd 6. ábra). Véleményünk szerint ugyanis, ha ismerjük azokat a tényezőket - akár mások kárán tanulva -, amelyek eufóriát, buborékot okozhatnak, akkor a követke-

\section{A KORÁBBI VÁLSÁGOK ISMERETE A VÁLASZADÓK KÖRÉBEN (\%)}

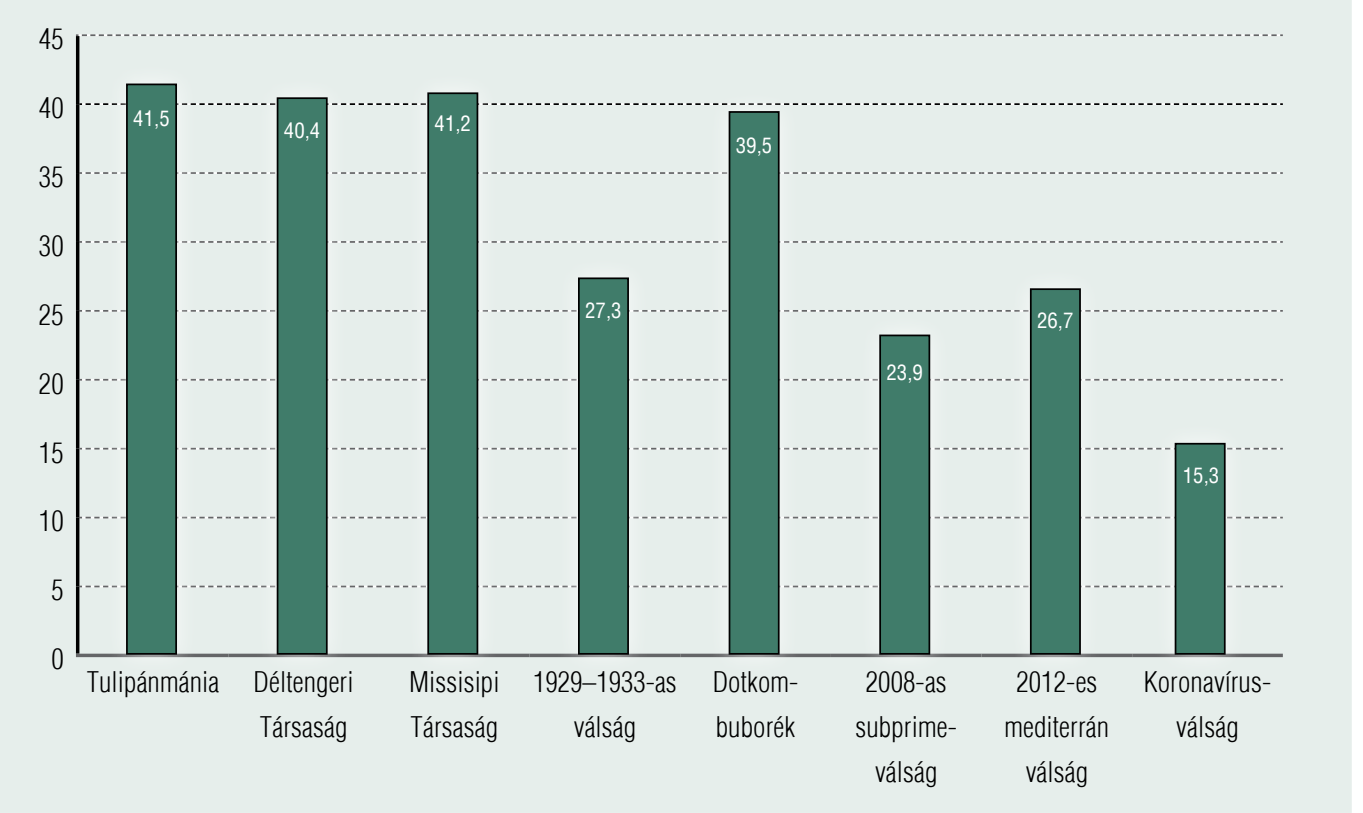

Forrás: saját kutatás, 2020; N = 6873 
ző válság során kevésbé károsodunk, szemben azokkal, akik a buborék aktív szereplői, szenvedő alanyai.

Az eredmények alapján a következő fő megállapításra jutottunk a válságok ismertségét illetően. A régebbi, hazánkban kisebb médiaaktivitást kapott események kapcsán nagyobb volt azok aránya, akik nem ismerik az adott válságot. A jelenhez közelebbi események kapcsán, amelyek nagyobb publicitást kaptak, egyes esetekben már bizonyos tananyagok részét képezik, jóval kisebb volt azok aránya, akik úgy nyilatkoztak, hogy nem ismerik az adott válságot.

Hipotézisünk (H1) szerint az egyes válságok ismertségét befolyásolja, hogy az alany milyen mértékben tájékozott a pénzügyi, gazdasági kérdések vonatkozásában. Azt feltételeztük, hogy összefüggés van az alany ebbéli képzettsége és a válságok ismertsége között.

A hipotézisvizsgálat érdekében a mintát csoportosítottuk azon válaszadókra (A csoport), akik az általunk vizsgált válságokat nem ismerték és azokra, akik igen (B csoport).

A statisztikai összefüggés értékeléséhez a Pearson-féle Khi-négyzet szignifikanciaértékét vettük alapul.

$\mathrm{Az}$ 1929-1933-as válság $(\operatorname{sig}=0,000)$ a 2008-as subprime-válság ( $\operatorname{sig}=0,003)$, és a koronavírus-válság (sig $=0,000)$ esetén tudtuk statisztikailag is igazolni, hogy a válság ismerete és a pénzügyi, gazdasági ismeretek megléte között összefüggés van. A többi vizsgált válság esetén a szignifikancia értéke nagyobb volt, mint 0,005 , így azok kapcsán a statisztikai öszszefüggés nem volt igazolható (H1 részben igazolódott).

$\mathrm{H} 1 / \mathrm{b}$ vizsgálata érdekében belső összefüggés-elemzést folytattunk le, amelyhez a korrigált sztenderdizált reziduumok értékeit használtuk fel. Ennek értelmében azon válságok kapcsán, amelyek ismerete szignifikáns összefüggést mutatott a pénzügyi, gazdasági ismeretek meglétével, megvizsgáltuk az alanyok elvárt értékhez képesti megoszlását. (Lásd 2., 3. és 4. táblázat)

$\mathrm{Az}$ eredmények alapján megállapíthattuk mindhárom - az 1929-1933-as, a 2008-as subprime- és a koronavírus-válság esetében, hogy, akik ismerik („A” csoport) az adott vál-

2. táblázat

\section{AZ 1929-1933-AS VÁLSÁG ISMERETE ÉS A PÉNZÜGYI, GAZDASÁGI TANULMÁNYOK MEGLÉTE KÖZÖTTI ÖSSZEFÜGGÉS-VIZSGÁLAT EREDMÉNYE}

\begin{tabular}{|c|c|c|c|c|}
\hline \multicolumn{2}{|c|}{ Az 1929-1933-as válság ismerete } & \multicolumn{2}{|c|}{$\begin{array}{l}\text { Tanult már pénzïgyi, gazdasági } \\
\text { ismereteket }\end{array}$} & \multirow{2}{*}{ Összesen } \\
\hline & & igen & nem & \\
\hline \multirow{2}{*}{$\begin{array}{l}\text { Nem ismeri az 1929-1933-as } \\
\text { válságot („A” csoport) }\end{array}$} & Alanyok & 716,0 & 1164,0 & 1880 \\
\hline & $\begin{array}{l}\text { Korrigált sztenderdizált } \\
\text { reziduum (Adj.R) }\end{array}$ & $-4,7$ & 4,7 & \\
\hline \multirow{2}{*}{$\begin{array}{l}\text { Ismeri az 1929-1933-as } \\
\text { válságot („B” csoport) }\end{array}$} & Alanyok & 2218,0 & 2775,0 & 4993,0 \\
\hline & $\begin{array}{l}\text { Korrigált sztenderdizált } \\
\text { reziduum (Adj.R) }\end{array}$ & 4,7 & $-4,7$ & \\
\hline Összesen & Alanyok & 2934,0 & 3939,0 & 6873,0 \\
\hline
\end{tabular}

Forrás: saját kutatás, 2020, N = 6873 
3. táblázat

\section{A 2008-AS SUBPRIME-VÁLSÁG ISMERETE ÉS A PÉNZÜGYI, GAZDASÁGI TANULMÁNYOK MEGLÉTE KÖZÖTTI ÖSSZEFÜ̈GÉS-VIZSGÁLAT EREDMÉNYE}

\begin{tabular}{|c|c|c|c|c|}
\hline \multicolumn{2}{|c|}{ A 2008-as subprime-válság ismerete } & \multicolumn{2}{|c|}{$\begin{array}{c}\text { Tanult már pénzitgyi, gazdasági } \\
\text { ismereteket }\end{array}$} & \multirow{2}{*}{ Összesen } \\
\hline & & igen & nem & \\
\hline \multirow{2}{*}{$\begin{array}{l}\text { Nem ismeri a 2008-as } \\
\text { subprime-válságot („A” } \\
\text { csoport) }\end{array}$} & Alanyok & 649,0 & 993,0 & 1642,0 \\
\hline & $\begin{array}{l}\text { Korrigált sztenderdizált } \\
\text { reziduum (Adj.R) }\end{array}$ & $-3,0$ & 3,0 & \\
\hline \multirow{2}{*}{$\begin{array}{l}\text { Ismeri a 2008-as subprime- } \\
\text { válságot („B” csoport) }\end{array}$} & Alanyok & 2285,0 & 2946,0 & 5231,0 \\
\hline & $\begin{array}{l}\text { Korrigált sztenderdizált } \\
\text { reziduum (Adj.R) }\end{array}$ & 3,0 & $-3,0$ & \\
\hline Összesen & Alanyok & 2934,0 & 3939,0 & 6873,0 \\
\hline
\end{tabular}

Forrás: saját kutatás, 2020, N = 6873

4. táblázat

\section{A KORONAVÍRUS-VÁLSÁG ISMERETE ÉS A PÉNZÜGYI, GAZDASÁGI TANULMÁNYOK MEGLÉTE KÖZÖTTI ÖSSZEFÜGGÉS-VIZSGÁLAT EREDMÉNYE}

\begin{tabular}{|c|c|c|c|c|}
\hline \multirow{2}{*}{\multicolumn{2}{|c|}{ Koronavírus-válság ismerete }} & \multicolumn{2}{|c|}{$\begin{array}{c}\text { Tanult már pénzitgyi, gazdasági } \\
\text { ismereteket }\end{array}$} & \multirow[t]{2}{*}{ Összesen } \\
\hline & & igen & nem & \\
\hline \multirow{2}{*}{$\begin{array}{l}\text { Nem ismeri a koronavírus- } \\
\text { válságot („A” csoport) }\end{array}$} & Alanyok & 390,0 & 659,0 & 1049,0 \\
\hline & $\begin{array}{l}\text { Korrigált sztenderdizált } \\
\text { reziduum (Adj.R) }\end{array}$ & $-3,9$ & 3,9 & \\
\hline \multirow[t]{2}{*}{ Ismeri a koronavírus-válságot } & Alanyok & 2544,0 & 3280,0 & 5824,0 \\
\hline & $\begin{array}{l}\text { Korrigált sztenderdizált } \\
\text { reziduum (Adj.R) }\end{array}$ & 3,9 & $-3,9$ & \\
\hline Összesen & Alanyok & 2934,0 & 3939,0 & 6873,0 \\
\hline
\end{tabular}

Forrás: saját kutatás, 2020, N = 6873

ságokat, azok körében az elvárt értékhez képest nagyobb arányban - (Adj.R.értékek = 4,7; 3,0; 3,9) - voltak jelen a pénzügyi, gazdasági tanulmányokkal rendelkezők. Az elvárt értékhez képest pedig kisebb arányban (Adj.R. értékek = $-4,7 ;-3,0 ;-3,9)$ az ilyen tanulmányok birtokában nem lévők.
Ezzel H1/b hipotézisünk beigazolódott, kimondható, hogy a releváns tanulmányoknak meghatározó szerep van a válságok iránti attitűd kognitív szintjének (ismeret, tudás) mikéntjére.

A következőkben $\mathrm{H} 2$ hipotézisünk vizsgálatának első etapjaként az adott válságot isme- 
rők körében azt elemeztük, hogy a mintatagok milyennek ítélik meg az egyes válságok hatását. A vizsgálatot nominális mérési szinten végeztük, ennek megfelelően az egyes minősítésekre adott százalékos értékek mentén értelmeztük az eredményeket. Az adott válságnak tulajdonított hatásokat a 7. ábra mutatja.

$\mathrm{Az}$ értékek alapján megállapítható, hogy a koronavírus hatását tartották a legtöbben (38,1 százalék) nagyon erősnek. Az eredmény meglátásunk szerint nem meglepő, hiszen az érintettség és az involváltság ezen válság esetében a legdominánsabb, az időbeli közelség, a félelmek friss mivolta is magyarázza az eredményt. Ezt követték azonos említési szint mellett (30,9 százalék) az 1929-1933-as és a 2008-as subprime-válságok. A Tulipánmánia (12,8 százalék), a Missisipi Társaság (10,8 százalék) vagy épp a Déltengeri Társaság válságát (11,9 százalék) csak kevesen értékelték nagyon erősnek, amelyet valószínűleg az érintettség kisebb mivolta épp úgy befolyásol, mint az időbeliség és az azokkal kapcsolatos információk, tájékoztatók száma, mértéke.

Megállapítható, hogy a válságok közül azon krízisek, amelyekkel a média és a közvélemény aktívan foglalkozott vagy foglalkozik, sokkal nagyobb észlelt hatással bírnak. Ez is az információáramlás, a tájékoztatás (az attitűd kognitív szakaszának) fontosságát és befolyásoló erejét igazolja. Azon válságok hatását, amelyek időben korábban történtek, vagy nem tartoztak a nagy érdeklődésre számító válságok körébe, kevésbé tartották a válaszadók nagy hatásúnak, még akkor is, ha ezek gazdasági, pénzügyi hatása világviszonylatban jóval jelentősebb volt, mint amilyennek a megkérdezettek azt tartották. Az eredmények azt is igazolják, hogy a vizsgált válságok hatásának érzékelésénél az információáramlás és a tájé-

\section{A VIZSGÁLt VÁLSÁGOK HATÁSÁNAK MEGíTÉLÉSE A VÁLASZADÓK KÖRÉBEN (\%)}

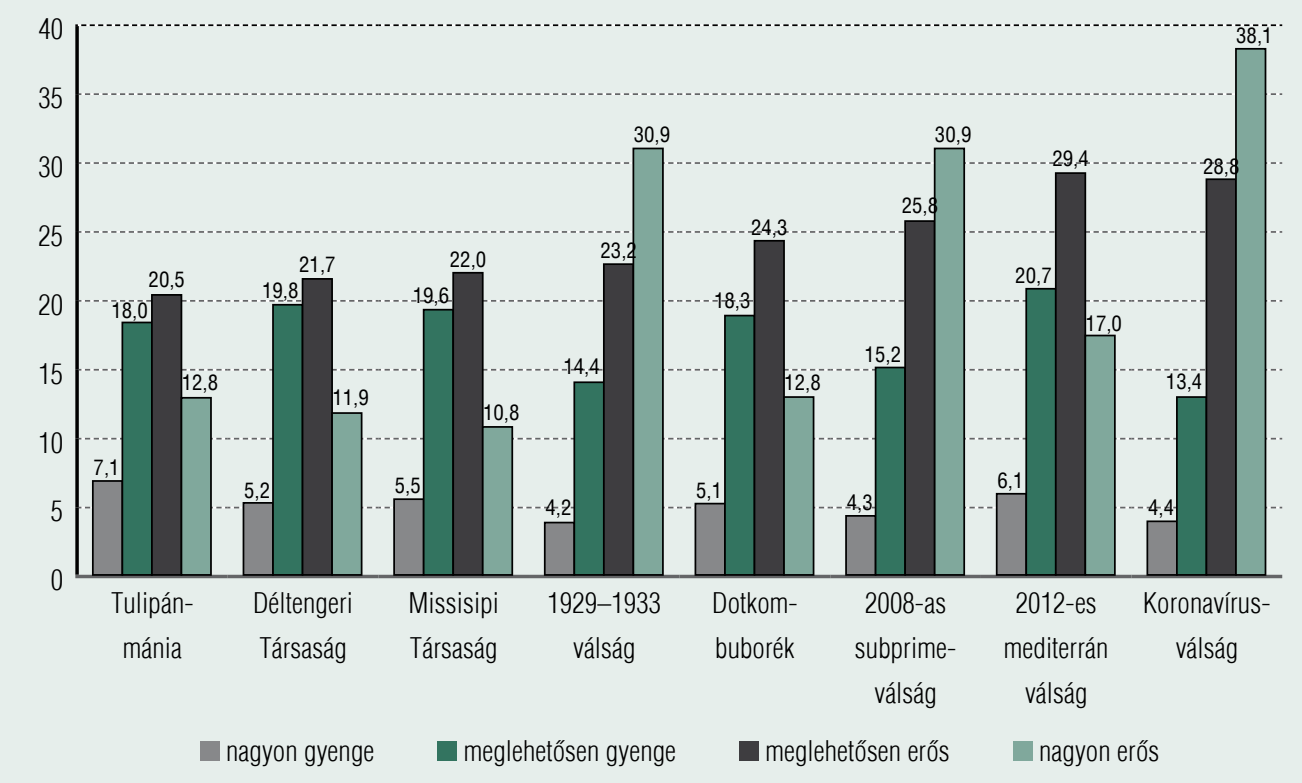

Forrás: saját kutatás, 2020, N = 6873 
koztatás dominanciájának befolyásoló ereje mellett releváns az etnocentrikus magatartás: a fogyasztó lakhelyétől, országától távolabbi, az adott fogyasztó mindennapjait kevésbé érintő válság hatását kevésbé érzi relevánsnak a válaszadó.

A vizsgálatba vont válságok hatásának mértéke és a pénzügyi, gazdasági ismeretek megléte közötti statisztikailag igazolható összefüggés elemzésénél a H1-es hipotézis Pearson-féle Khi-négyzet értékei értelmében három válság kapcsán volt igazolható releváns kapcsolat. A belső összefüggések elemzése céljából - a módszertanilag ezen a mérési szinten alkalmazható - korrigált sztenderdizált reziduumok értékeit vontuk a vizsgálatba. A reziduumok értékei szerint megállapíthattuk, hogy mind az 1929-1933-as, mind a 2008-as subprime- és a koronavírus-válság hatását nagyon erősnek minősítők között az elvárt értékhez képest nagyobb arányban voltak jelen a pénzügyi, gazdasági tanulmányokkal rendelkező válaszadók (korrigált sztenderdizált reziduum=Adj. $\mathrm{R}=7,7 ; 4,7 ; 2,4)$. Akik ilyen ismeretekkel nem rendelkeznek, azok körében az elvárthoz képest kisebb arányban voltak jelen az adott válságok hatását erősnek minősítők (korrigált sztenderdizált reziduum=Adj. $\mathrm{R}=-7,7 ; \quad-4,7$; $-2,4)$. Ezzel szemben az elvárthoz képest nagyobb arányban képviseltették magukat a 2008-as subprime- és a koronavírus-válság hatását nagyon gyengének minősítők között (korrigált sztenderdizált reziduum $=A d j . R=$ $3,9 ; 3,8)$. H2 hipotézisünk ezzel beigazolódott. (Lásd 5. táblázat)

Az eredmények alapján elmondható, hogy a pénzügyi és gazdasági tanulmányok megléte befolyással bír az egyes válságok, így a jelenben leginkább relevánsan ható koronavírusválság ismeretére és hatásának megítélésére is. Az eredmények igazolják, hogy az attitűd kognitív szintjének stabil megléte mérvadó abban, hogy a válságok megítélése releváns legyen és ezzel egy téves megítélést eredményező kognitív disszonancia ne álljon fel. A pénzügyi oktatásnak, a megfelelő pénzügyi és gazdasági ismeretek átadásának fontosságára hívják fel ezen eredmények is a figyelmet.

5. táblázat

\section{VIZSGÁLATBA VONT VÁLSÁGOK HATÁSÁNAK MÉRTÉKE \\ ÉS A PÉNZÜGYI, GAZDASÁGI ISMERETEK MEGLÉTE KÖZÖ̈TII ÖSSZEFÜGGÉS-VIZSGÁLAT EREDMÉNYE}

\begin{tabular}{|c|c|c|c|c|c|}
\hline \multirow{2}{*}{$\begin{array}{l}\text { A gazulasági, pénzitgyi } \\
\text { ismeretek meglétével } \\
\text { szignifflkáns összeffiggést } \\
\text { mutató válságok }\end{array}$} & \multirow{2}{*}{\begin{tabular}{c|} 
Gazdasági, \\
pénzitgyi \\
ismereteket
\end{tabular}} & \multicolumn{4}{|c|}{ Vizsgálatha vont vấlság hatásának mértéke } \\
\hline & & Nagyon gyenge & $\begin{array}{c}\text { Meglehetősen } \\
\text { gyenge }\end{array}$ & $\begin{array}{l}\text { Meglehető́sen } \\
\text { erớs }\end{array}$ & Nagyon erốs \\
\hline \multirow[t]{2}{*}{ 1929-1933-as válság } & Tanult & Adj. $R=0,3$ & Adj. $R=-5,0$ & Adj. $R=0,6$ & Adj. $R=7,7$ \\
\hline & Nem tanult & Adj. $R=-0,3$ & Adj. $R=5,0$ & Adj. $R=-0,6$ & Adj. $R=-7,7$ \\
\hline \multirow[t]{2}{*}{ 2008-as subprime-válság } & Tanult & Adj. $R=3,9$ & Adj. $R=-1,8$ & Adj. $R=-2,4$ & Adj. $R=4,7$ \\
\hline & Nem tanult & Adj. $R=-3,9$ & Adj. $R=1,8$ & Adj. $R=2,4$ & Adj. $R=-4,7$ \\
\hline \multirow[t]{2}{*}{ Koronavírus-válság } & Tanult & Adj. $R=3,8$ & Adj. $R=0,4$ & Adj.R= 0,3 & Adj. $R=2,4$ \\
\hline & Nem tanult & Adj. $R=-3,8$ & Adj. $R=-0,4$ & Adj. $R=-0,3$ & Adj. $R=-2,4$ \\
\hline
\end{tabular}

Forrás: saját kutatás, 2020, N = 6873 


\section{ÖSSZEGZÉS}

A bemutatott kutatási eredmények rávilágítanak arra, hogy a pénzügyi kultúra mennyire fontos része a gazdaságtörténet is. A gazdasági múlt ismerete a válságok képében kiemelt jelentőségű, hiszen a korábbi krízisek, a buborékok természetének ismerete számos rossz gazdasági, így pénzügyi döntéstől is megóv minket. Ha ismerjük a válságok és buborékok természetét, kialakulásának körülményeit, akkor az hozzá tud segíteni a jobb financiális döntéshozatalhoz. A kutatás eredményei alátámasztják, hogy a korábbi pénzügyi oktatás segít abban, hogy jobban és pontosabban lássuk a múlt válsága- it, képessé téve minket a reálisabb ténylátásra. Az is világossá vált, hogy a pénzügyi oktatás önmagában nem megoldás, ott sokkal hangsúlyosabban kellene foglalkozni a válságokkal, mélyrehatóan tanulmányozva, és következtetéseket megfogalmazva azokból. E feladat tekintetében kifejezetten fontos szerepe van az oktatásnak, föként a felsőoktatásnak, ahol van arra lehetőség, hogy akár külön kurzus keretében is foglalkozzunk a régmúlt és a közelmúlt válságaival. Saját tapasztalataink alapján elmondhatjuk, hogy erre igény is mutatkozik, így megfontolandó a pénzügyi műveltség fejlesztésének eme szeletével kiegészíteni a palettát, a sokrétű pénzügyi kultúra kialakítása fényében.

\section{JEGYZETEK}

1 Egyirányú, hosszabb távon stabil

2 „Ha a szomszéd munkanélküli lesz, az recesszió, ha Te leszel az, az már depresszió.”(Harry S. Truman)

\section{IRODALOM}

Atrinson, A., Messy, F. A. (2012). Measuring Financial Literacy: Results of the OECD / International Network on Financial Education (INFE) Pilot Study. OECD Working Papers on Finance, Insurance and Private Pensions, Paris

Beshenov, S., Rozmainsky, I. (2015). Hyman Minksy's Financial Instability Hypothesis and the Greek Debt Crisis. Russian Journal of Economics, 1 (2015), pp. 415-438

Béres D., Huzdik K. (2012). A pénzügyi kultúra megjelenése makrogazdasági szinten. Pénzügyi Szemle, 2012/2, 322-336. oldal
Botos K., Botos J., Béres D., Csernák J., NÉMETH E. (2012). Pénzügyi kultúra és kockázatvállalás a közép-alföldi háztartásokban. Pénzügyi Szemle, 2012/2, 291-309. oldal

Davidson, P. (2002). Restating the Purpose of the JPKE after 25 Years Journal of Post Keynesian Economics. Vol. 25, No. 1 (Autumn), Taylor \& Francis, Ltd., pp. 3-7, https://www.jstor.org/stable/4538808

FARKas F. (2013). A változásmenedzsment elmélete és gyakorlata. Akadémia Kiadó, Budapest

Greiner, L. (2009). Evolution and Revolution as Organizations Grow. University of Illinois at 
Urbana-Champaign's Academy for Entrepreneurial Leadership Historical Research Reference in Entrepreneurship. Posted: 17 Nov 2009

Huston, S. J. (2010). Measuring Financial Literacy. The Journal of Consumer Affairs, Vol. 44, No. 2, pp. 296-316

Kehl D., Sipos B. (2007). Évszázados trendek és hosszú ciklusok az Amerikai Egyesült Államokban, Kínában és a világgazdaságban. Hitelintézeti Szemle, VI. évf. III. szám, 248-282. oldal, http:// epa.oszk.hu/02700/02722/00028/pdf/EPA02722_ hitelintezeti_szemle_2007_03_248-282.pdf

Kovács P., RévéSz B., OrszáG G.-NÉ (2012). A pénzügyi kultúra és attitűd mérése. Szegedi Tudományegyetem, Gazdaságtudományi Kar, Szeged

Lentner, Cs. (2015). A lakossági devizahitelezés kialakulásának és konszolidációjának rendszertani vázlata. Pénzügyi Szemle, 2015/3, 305-318. oldal

Lusardi, A., Mitchell (2014). The Economic Importance of Financial Literacy: Theory and Evidence. Journal of Economic Literature, Vol. LII. march, pp. 5-44

Mandell, L., Schmid Klein, L. (2009). The Impact of Financial Literacy Education on Subsequent Financial Behavior. Journal of Financial Counseling and Planning, Vol. 20, No. 1, pp. 15-24

MadARÁsz A. (2009). Buborékok és legendák Válságok és válságmagyarázatok - a tulipánmánia és a Déltengeri Társaság. I. rész, Közgazdasági Szemle, LVI. évf., július-augusztus, 609-633. oldal

Madarász A. (2011a). Buborékok és legendák Válságok és válságmagyarázatok -a Déltengeri Társaság. II/1. rész, Közgazdasági Szemle, LVIII. évf., november, 909-948. oldal

Madarász A. (2011b). Buborékok és legendák -
Válságok és válságmagyarázatok - a Déltengeri Társaság. II/2. rész, Közgazdasági Szemle, LVIII. évf., december, 1001-1028. oldal

Németh E., Vargha B., Domokos K. (2020). Pénzügyi kultúra. Kik, kiket és mire képeznek? Öszszehasonlító elemzés 2016-2020. Pénzügyi Szemle, 2020/4, 554-582. oldal

PÁlinkai T., Miklós G. (2014). Globalizációs indexek (kísérletek a globalizációs integráció mérésére). Magyar Tudomány, 2014/6 http:// epa.oszk.hu/00600/00691/00129/pdf/EPA00691_ mtud_2014_06_692-712.pdf

SÁgi J., Vasa L., Lentner Cs. (2020a). Innovative Solutions in the Development of Households' Financial Awareness: A Hungarian Example. Economics and Sociology, Vol. 13, No. 3, pp. 27-45, https://doi.org/10.14254\%2F2071-789X.2020\%2 F13-3\%2F2

Sági, J., Chandler, N., Lentner, Cs. (2020b). Family Businesses And Predictability Of Financial Strength: A Hungarian Study. Problems and Perspectives in Management, Vol. 18, No. 2, pp. 476-489, https://doi.org/10.21511\%2Fppm.18\%282\% 29.2020 .39

Shostak, F. (2007). The Hyman Minsky Theory does not Explain the Current Financial Crisis, BrookesNews.Com, http://www.brookesnews.com/ 070312minsky_print.html

SüGE, Cs. (2010). A pénzügyi kultúra mérhetősége. In: Tompáné Daubner Katalin - Miklós György (szerk.) Tudományos Mozaik 7. Második kötet Kalocsa, Tomori Pál Főiskola

Tepperwein, K. (2000). Milliomos bárki lehet. Édesvíz Kiadó, Budapest

Weiß, J., Sachs, A., Weinelt, H. (2018). Globalization Report Who Benefits Most from 
Globalization? Bertelsmann Stiftung Bertelsmann Stiftung Gütersloh. http://www.iberglobal.com/ files/2018-2/MT_Globalization_Report_2018.pdf

XU, L., ZIA, B. (2012). Financial Literacy around the World, an Overview of the Evidence with Practical Suggestions for the Way Forward. The World Bank Development Research Group Finance and Private Sector Development Team, Policy Research Working Paper, June 2012

Aegon.hu (2020). https://www.aegon.hu/hirek/ magyarok-43-szazalekanak-nincs-megtakaritasa. html

Atlas of Economic Complexity (2020). Country and Product Complexity Rankings. http://atlas.cid. harvard.edu/rankings

Council of the European Union (2020). Bankunió.https://www.consilium.europa.eu/hu/policies/ banking-union/

European Commission (2020). What is the Capital Markets Union? General Information on the Objectives of the Capital Markets Union. https:// ec.europa.eu/info/business-economy-euro/growthand-investment/capital-markets-union/whatcapital-markets-union_hu

ETH Zürich KOF Institute (2020). The KOF Globalization Index 2020. https://kof.ethz. ch/en/forecasts-and-indicators/indicators/kofglobalisation-index.html

MNB (2008). Együttműködési megállapodás a pénzügyi kultúra fejlesztéséről. Vol. 2012. Budapest

Növekedés.hu (2020). https://novekedes.hu/ hirek/atlagosan-400-ezer-forint-megtakaritasa-vanegy-magyar-fiatalnak-de-45-szazaleknak-nincsfelretett-penze

Piac és profit (2020). https://piacesprofit.hu/ gazdasag/a-magyarok-tobbsege-csak-hallomasbolismeri-a-megtakaritasokat/

The Observatory of Economic Complexity (2020). The Economic Complexity Ranking. https://oec.world/en/rankings/eci/hs6/hs12

The World Economic Forum (2020). These are the Most Complex Economies Around the Globe., https://www.weforum.org/agenda/2019/12/ countries-ranked-by-their-economic-complexity/

United Nations Conference On Trade And Development UNCTAD (2020). The World Investment Report 2020 International Production Beyond the Pandemic. https://unctad.org/system/ files/official-document/wir2020_en.pdf

24. hu (2020). https://24.hu/fn/gazdasag/2020/ 12/04/nyugdij-takarekossag/ 